\title{
UN DIÁLOGO SELECTO: GÓNGORA Y PACO IBÁÑEZ
}

Marcela Romano

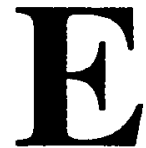

1 presente trabajo tiene como objeto descubrir las claves de una lectura: la que hace Paco Ibáñez de los textos de Luis de Góngora y Argote. Porque es, sin duda, una lectura, esto es, una "versión" particular, en fin, una "traducción”, el álbum de Ibáñez editado en 1964, ${ }^{1}$ al calor del movimiento de la "nueva canción" hispana, que recoge, en su programa formal e ideológico, el primer impulso de la poesía "social" consagrada: el retorno a la "inmensa mayoria" de Blas de Otero, la apuesta por el coloquialismo y las hablas populares, el fin de la "videncia" y la "demiurgia" modernas. La primera pregunta que nos hacemos es ¿cómo pensar a Góngora en este contexto? ¿cómo conciliar las imágenes fantasmáticas de uno de los poetas mas herméticos y esteticistas de la tradición española con esta impronta "engagée" de los 60 ? Ibáñez, parece, se atreve a todo. Pero no tanto.

* Universidad Nacional de Mar del Plata.

1 Cf. IBÁÑ̃Z, Paco. Paco lbánez. Poemas de Federico García Lorca y Luis de Góngora. Polydor, 62139 (1984). 


\section{Construyendo nuestro objeto de análisis}

Hablar de Paco Ibáñez es hablar de poesía musicalizada en lengua española. Y, en este sentido, resulta necesario precisar y definir este objeto, que no es "poesía", en los términos institucionales en que se habla de ella, ni tampoco "canción", porque en su constitución aparece como insoslayable su remisión al sistema de la poesía consagrada, académica, "culta".

Al estudiar la canción española (e incluso la hispanoamericana), advertimos que este aspecto ha asumido una especial ingerencia en la constitución del género y de ello da cuenta una larga lista de poetas entre los que se cuentan: Rafael Alberti, Federico García Lorca, León Felipe, Gabriel Celaya, Gustavo A. Bécquer, los Machado, Quevedo, Góngora, Juan de la Cruz...

La trasmutación intersemiótica originada por estos procedimientos permite encuadrar la musicalización de poesía consagrada dentro del sistema polimorfo y heterogéneo de las prácticas de "traducción", lo que exige la constitución prioritaria de una vía de exploración comparatística que dé cuenta de las alternancias producidas entre el texto inicial o poema (TI) y el texto terminal o canción (TT), tanto en sus características formales como contextuales: se trata, en definitiva, de observar los procesos de "traducción" (diálogo, apropiación, reacentuación, variación) no sólo entre textualidades sino también, y especialmente, entre campos, imaginarios y políticas culturales, sociales, históricos, ideológicos.

Desglosemos lo esbozado en el párrafo anterior. Concebimos la operación de musicalización de textos consagrados como una operación de traducción intersemiótica, aplicando uno de los tres tipos distinguidos por Roman Jakobson, al referirse a procesos de traducción dados entre la lengua y otro sistema no exclusivamente lingüístico.

En el caso que nos ocupa, el poema es transcodificado para su ingreso en un sistema de signos más complejo, donde encontramos, en un nivel de existencia virtual, el texto verbal originario, en su hechura inicial, o (lo más frecuente), transformado y reorientado: el mismo pudo ser abreviado, sus versos estribillados, sus estrofas reubicadas o combinadas con otras de otros poetas o de la autoría del cantautor. Convive con el texto verbal un texto musical, creado por el compositor, adaptado a las pautas musicorrítmicas del primero o adaptado, por lo mismo, de éste último. En una segunda instancia, donde este producto virtual es efectivamente actualizado, contamos con dos nuevos sistemas semióticos: un texto vocal, de sentido tan variable como los sujetos que lo llevan a cabo, y un texto espectacular, con la misma productividad significante. 
Ambos, por lo mismo, portan consigo una importante carga de información connotativa que se suma a la generada desde lo verbal.

De este modo, el texto "fuente", "original", "inicial", que pertenecía excluyentemente al sistema escrito de la literatura consagrada, ha sido "traducido", y, con este acto, se ha desprendido (en parte) de su naturaleza escrituraria para ingresar en dos sistemas de los que se distanciaba: los medios de comunicación y el espectáculo, desde una nueva formulación, ahora oral.

En este sentido, según anticipamos, un primer paso de nuestra investigación debería ser la creación de un modelo de cotejo comparatístico, que permita describir e interpretar las transmutaciones experimentadas desde la fuente al objeto terminal, en sus diversos niveles. Por ejemplo, la indagación minuciosa de los textos originales en su co-texto respectivo y el andamiaje crítico generado en su entorno, las imágenes de autor contemporáneas y tardías, la recepción epocal, etc. Con respecto al texto "canción" podríamos reconstruir la razón de las decisiones operadas en la abreviación, reorientación y combinación (con otros textos) del poema originario; analizar la relación establecida con los textos musicales, en sus distintas versiones; estudiar el material semiótico aportado por los textos de actualización (el vocal y el espectacular), etc.

Ahora bien, la transmutación supone, al margen de las modificaciones semióticas internas, el nacimiento de un nuevo objeto discursivo que es necesario estudiar en una compleja red de relaciones con:

a. un co-texto diferente (el álbum en que se inserta, las letras de las otras canciones, la secuenciación u orden "espectacular", etc.).

b. una serie de sistemas nuevos: el sistema cancioneril (canción de "autor") dentro del cual funciona; otros sistemas, como la canción de "consumo" y prácticas similares, dentro de los medios de comunicación; las prácticas discursivas metatextuales (periodismo, crítica especializada, etc.) emergentes; el género de lo musicalizado $\mathrm{y}$, dentro del mismo, las distintas versiones en circulación, y también las distintas vocalizaciones generadas a partir de una misma versión; el sistema de la literatura consagrada (en diálogo oblicuo, ahora desde su oralidad); el sistema de las artes del espectáculo, etc.

c. el contexto sociohistórico vigente: comparación de las condiciones de recepción del poema original y la canción; desentrañamiento de los contextos interpretativos vigentes, cuya operatividad es significativa en el rediseño de] texto de base por parte del compositor, quien, en primera instancia, también es 
ROMANO, M. Un diálogo selecto: Góngora...

un receptor. En este punto, asimismo, resulta operativa la indagación en torno a las imágenes o figuras de autor, tanto la del poeta como la del musicalizador. ${ }^{2}$

\section{Luis de Góngora por Paco Ibáñez: travesias y desplazamientos}

\section{Retrato de autor con metáfora de fondo}

Luis de Góngora ha sido el poeta áureo más demonizado y exaltado de la literatura española. Su personalidad, polémica, se suma a una producción también polémica, en diversos sentidos. "Príncipe de la luz" y "príncipe de las tinieblas" lo llamó Francisco Cascales, un contemporáneo suyo, para dar cuenta de su obra total. Por una parte, el aire fresco del romancero tradicional y la poesía popular, incorporados a sus letrillas y romances, donde los juegos de infancia, las fiestas y la burla ácida y corrosiva constituyen los motivos dominantes: la "luz". Por otra, cl mundo desrrealizado de sus obras "mayores" (Polifemo, las Soledades), críptico y transitable sólo para iniciados, en el cual la imagen termina sólo refiriéndose a sí misma, en un juego autista en el que lo "real" termina fagocitado, en el constante desplazamiento metafórico, por el lenguaje: las "tinieblas" del llamado "gongorismo", que, en el siglo barroco, lleva a su máxima tensión la poética cultista inaugurada en el siglo anterior.

Dados su complejidad, y su carácter altamente polémico y diferencial respecto de otras poéticas coetáneas y posteriores, esta segunda zona de la producción gongorina es la que, de una parte, ha recibido la mayor atención crítica, y, por otra, ha generado la "imagen de autor Góngora" dominante en el

2 Al respecto, ha sido principalmente Dámaso Alonso, quien, en 1935 primero, y en succsivos ensayos luego, ha intentado destrabar esta complejidad gongorina a través del estudio, riguroso y pormenorizado, de su retórica. De este modo, sus libros y artículos dan cuenta de los recursos y tropos más empleados por el poeta: cultismos, alusiones (mitológicas, fabulosas,etc.), metáforas, metonimias, hipérbaton, perifrasis, paronomasias, plurimembraciones, etc. De hecho, la lectura de su Polifemo, aún para el lector más competente, necesita de la mediación que Dámaso Alonso ofrece en una suerte de "traducción" esclarecedora en su edición anotada. Cf. ALONSO, Dámaso. Góngora y el Polifemo. v. 3. Madrid: Gredos, 1974. En el mismo sentido, para la lectura comprensiva de las Soledades, resultan indispensables las ediciones de este mismo autor (Soledades. Madrid: Alianza, 1980) y de John Beverly (Soledades. Madrid: Cátedra, 1985), entre otras. 
ROMANO, M. Un diálogo selecto: Góngora...

campo intelectual y académico. A la cristalización de esta imagen ha contribuido, decididamente, la vanguardia española del 27, la cual, luego de siglos de ostracismo, ${ }^{3}$ rescata a Góngora como precursor de su programa y de su praxis literarios. En este sentido, la conferencia pronunciada por García Lorca en 1927 podría constituirse en el paradigma de lectura que del poeta cordobés hace toda esa generación, y la que se mantiene, de manera protagónica, hasta hoy. ${ }^{4}$

No obstante, y de acuerdo con la datación de su producción, la crítica posterior a Góngora, hasta la actualidad, pone en cuestión esta división tajante señalada por Cascales; el Góngora popular y el cultista convivieron y no se sucedieron, como podría pensarse, y esta convivencia, esta relación transversal entre poéticas pone en cuestión, también, su exclusión mutua: una lectura atenta de su obra revela los cruces, los pactos, las interferencias constantes entre cultura "erudita" y cultura "popular" que anidan en sus textos, cuya relación diferencial debe sostenerse más en términos de predominio que de oposición. ${ }^{5}$

3 Según apunta Dámaso Alonso, el influjo de Góngora entre sus contemporáneos fue poderosísimo, no sólo en España, sino también en Portugal e Hispanoamérica. Los siglos XVIII y XIX, en cambio, se resisten a aceptarlo abiertamente, y, más de una vez, su poesía es duramente estigmatizada. Alonso cita unas palabras del poeta Manuel José Quintana que bien sirven de ejemplo respecto de esta actitud: "[...] dio consigo en un abismo de extravagancias y delirios; en una jerigonza detestable, tan opuesta a la verdad como a la belleza, y que al paso que fue seguida por una muchedumbre de ignorantes, fue reprobada por cuantos conservaban todavía un poco de juicio y sensatez". Cf. ALONSO, Dámaso. Góngora y el Polifemo. v. 1. Madrid: Gredos, 1974. p. 261.

4 Cf. GARCÍA LORCA, Federico. La imagen poética en Don Luis de Góngora. In: Obras completas. v. 7. Bs. As. Losada, 1952. p. 85-116. Las vinculaciones entre Góngora y el programa vanguardista "experimental" se revelan elocuentemente en el siguiente párrafo, que citamos a modo de ejemplo: "Mientras que todos piden el pan, él pide la piedra preciosa de cada día. Sin sentido de la realidad real, pero dueño absoluto de su realidad poética. ¿Qué hizo el poeta para dar unidad y proporciones justas a su credo estético? Limitarse. Hacer examen de conciencia, y con su capacidad crítica, estudiar la mecánica de su creación" (p. 92) (Los subrayados son nuestros).

5 El mismo Dámaso Alonso señala la provisionalidad de estas fronteras en su obra Góngora y el Polifemo (v. II, p. 95 y ss.) y también Emilio Orozco Díaz (Introducción a Góngora. Barcelona: Crítica, 1984). Artículos específicos, por otra parte, estudian en concreto este intercambio y cruce de imaginarios. Cf. por ejemplo, Antonio García Berrío, Las letrillas de Góngora: estructura pragmática y liricidad del género), en Edad de Om, v. 2, p. 89-97, 1983, y Robert Jammes, Elementos burlescos en las Soledades de Góngora, en Edade de Oro, v. 2, p. 99-117. 
ROMANO, M. Un diálogo selecto: Góngora...

\section{Breves sobre Paco Ibáñez}

En el contexto de la canción "de autor" española de los 60, Paco Ibáñez representa uno de los mitos fundacionales. Varios poetas de ayer y de hoy moldearon su heterodoxo camino: desde los anónimos de los romances, el Arcipreste de Hita, Jorge Manrique, Francisco de Quevedo, José de Espronceda, hasta Rubén Dario, Federico García Lorca, Miguel Hernández, Antonio Machado, Gabriel Celaya, Rafael Alberti, León Felipe, José Agustín Goytisolo, Blas de Otero, Pablo Neruda, Nicolás Guillén y otros. Nacido en Alicante en 1934 en una familia de republicanos combatientes, conoció el exilio, por primera vez a los catorce años, y el exilio se constituyó en condición vital permanente, de la cual nunca se ha apartado. Su figura autor se forja al calor de esta experiencia biográfica y de sus postulados estéticos, ligados a la propuesta de una poesía "revolucionaria", de una canción de "protesta", de una palabra que sea, como dice Gabriel Celaya, "arma cargada de futuro". Dos gestos públicos, archivados en la memoria de unos cuantos, colaboran también en la cristalización de este perfil: el recordado recital en La Comedia de Madrid, en plena época franquista, y el del 69 en la Sorbona, a un año del mayo francés. Hoy todavía sigue apostando, en desacuerdo con la modernización de "imagen" de algunos de sus compañeros de ruta, al espectáculo sobrio, con el solo acompañamiento de una guitarra, y para un público más que reducido. ${ }^{6}$

En relación complementaria con esta construcción simbólica de su nombre, hay razones estéticas para atribuir a Paco Ibáñez un perfil prioritariamente "social". Como muchos de los musicalizadores de su tiempo, y en función de su inscripción artística e ideológica, elige zonas determinadas de la literatura española para operar: estas zonas son las de las poéticas llamadas, en un sentido general, "sociales", "realistas", "referenciales", "populares", en polémica con otras poéticas, llamadas, también en un sentido general, "experimentales", "rupturistas", "esteticistas". En la serie literaria de la poesía española contemporánea, las poéticas "sociales" emergen en las décadas del 50 y 60 , confor-

6 En su último recital en Mar del Plata, nos dijo: "Para nosotros [esta canción] es una profesión de fe que se mantiene viva. Sin embargo, en el camino uno va despidiéndose de tanta gente.[...] Tú no lo crees, no lo quieres creer, pero al final te das cuenta de que el ochenta por ciento de la sociedad se ha despedido de ti [...] Hemos venido de España a hacer [este espectáculo] por ese otro veinte por ciento, que es el que vale la pena". Cf. ROMANO, Marcela. Escribir, decir, cantar: una utopía empecinada. Charlando con José A. Goytisolo y Paco Ibáñez (entrevista), en Revista del CELEHIS, año 4, v. 4/5, p. 330, 1995. 
ROMANO, M. Un diálogo selecto: Góngora...

mando un paradigma distanciado respecto de las poéticas "modernas", afianzadas en la serie romanticismo-modernismo-vanguardia. Los "sociales" de la primera y segunda "generaciones de posguerra" dan muerte a sus "padres" (siguiendo a Bloom) con un gesto radical que invierte la ideología poética precedente: si los "modernos" habían construido la imagen del poeta como un ser superior, vidente, demiúrgico, ahora ese mismo poeta es, simplemente, un obrero especializado de la palabra, en relación igualitaria con el resto de los hombres; si la palabra poética traducía una realidad trascendente y atemporal, ahora es un instrumento de la revolución, un arma para cambiar la historia, o, simplemente, para dar cuenta de la aventura cotidiana, temporal, del hombre concreto; si aquella poesía, por su carácter sagrado, exigía receptores "iniciados", ahora quiere encontrarse con un destinatario colectivo y común, en lo posible no académico; si el hermetismo y la dificultad retórica eran las señas de identidad de esta poesía "experimental", ahora la palabra busca allanarse, coloquializarse, volverse oral, transparente, inteligible. En este contexto, en el que las palabras piden, desde su propia virtualidad, ser comunicadas (cantadas), es explicable la opción de los musicalizadores con éstos y otros autores, cronológicamente más distanciados, pero sin duda precursores de su propia praxis poética: los poetas del romancero tradicional español, el Arcipreste, el Quevedo satírico, el Alberti neopopularista y... el Góngora de las letrillas y los romances. El problema se presenta en la condición dual de la poética gongorina que señalamos anteriormente y a la que adscribimos: si los Góngora "culto" y "popular" conviven a lo largo de toda la producción del autor, y si sabemos, además, que Góngora no sólo es un poeta "culto", sino "hiperculto" (porque, dijimos, exaspera hasta extremos intolerables para los "clásicos" la corriente cultista del siglo XVI)... ¿cómo traducirlo al sistema de la canción, que, en continuidad con los postulados de la poesía "social", se autoproclama excluyentemente "popular" y "de protesta", en una década, la del 60, donde los discursos culturales expulsan de su seno todo esteticismo y elitismo?

En relación complementaria con esta construcción simbólica de su nombre, hay razones estéticas para atribuir a Paco Ibáñez un perfil prioritariamente "social". Como muchos de los musicalizadores de su tiempo, y en función de su inscripción artística e ideológica, elige zonas determinadas de la literatura española para operar: estas zonas son las de las poéticas llamadas, en un sentido general, "sociales", "realistas", "referenciales", "populares", en polémica con otras poéticas, llamadas, también en un sentido general, "experimentales", "rupturistas", "esteticistas". En la serie literaria de la poesía española contemporánea, las poéticas "sociales" emergen en las décadas del 50 y 60 , conformando un paradigma distanciado respecto de las poéticas "modernas", 
ROMANO, M. Un diálogo selecto: Góngora...

afianzadas en la serie romanticismo-modernismo-vanguardia. Los "sociales" de la primera y segunda "generaciones de posguerra" dan muerte a sus "padres" (siguiendo a Bloom) con un gesto radical que invierte la ideología poética precedente: si los "modernos" habían construido la imagen del poeta como un ser superior, vidente, demiúrgico, ahora ese mismo poeta es, simplemente, un obrero especializado de la palabra, en relación igualitaria con el resto de los hombres; si la palabra poética traducía una realidad trascendente y atemporal, ahora es un instrumento de la revolución, un arma para cambiar la historia, o, simplemente, para dar cuenta de la aventura cotidiana, temporal, del hombre concreto; si aquella poesía, por su carácter sagrado, exigía receptores "iniciados", ahora quiere encontrarse con un destinatario colectivo y común, en lo posible no académico; si el hermetismo y la dificultad retórica eran las señas de identidad de esta poesía "experimental", ahora la palabra busca allanarse, coloquializarse, volverse oral, transparente, inteligible. En este contexto, en el que las palabras piden, desde su propia virtualidad, ser comunicadas (cantadas), es explicable la opción de los musicalizadores con éstos y otros autores, cronológicamente más distanciados, pero sin duda precursores de su propia praxis poética: los poetas del romancero tradicional español, el Arcipreste, el Quevedo satírico, el Alberti neopopularista y... el Góngora de las letrillas y los romances. El problema se presenta en la condición dual de la poética gongorina que señalamos anteriormente y a la que adscribimos: si los Góngora "culto" y "popular" conviven a lo largo de toda la producción del autor, y si sabemos, además, que Góngora no sólo es un poeta "culto", sino "hiperculto" (porque, dijimos, exaspera hasta extremos intolerables para los "clásicos" la corriente cultista del siglo XVI)... ¿cómo traducirlo al sistema de la canción, que, en continuidad con los postulados de la poesía "social", se autoproclama excluyentemente "popular" y "de protesta", en una década, la del 60 , donde los discursos culturales expulsan de su seno todo esteticismo y elitismo?

\section{En torno a una "versión"}

El álbum que estudiamos incluye, en su lado A, textos musicalizados de Federico García Lorca, extraídos de poemarios tempranos, y que corresponden a su vertiente de poesía neopopularista (en este caso, ligada al repertorio popular infantil), tendencia cultivada también por Rafael Alberti, dentro de la misma generación. El lado B está dedicado totalmente a Luis de Góngora, e incluye las siguientes versiones musicalizadas: "La más bella niña", "Que se nos va la Pascua, mozas", "Y ríase la gente", "Lloraba la niña", "Hermana Marica" y "Bien puede ser, no puede ser". 
Tratemos de ver, ahora, la razón de las decisiones por las que el musicalizador ("adaptador" o, digámoslo sin vueltas, "traductor") Ibáñez elige a este poeta, estos poemas, y los trabaja de esta manera.

Primera pregunta: ¿Por qué Góngora? Posibles respuestas: 1. Góngora es un poeta de la tradición española que debe ser conocido por un público más amplio que el de los claustros académicos y el de las escuelas poéticas. En este sentido, Ibáñez en particular, y la canción de "autor" en general se proponen, a través del espectáculo y de los medios masivos, la promoción de una canción "diversa" (Eco) de la llamada "de consumo", pobre y repetitiva en su estructura musical y verbal; de esta forma, la apelación al repertorio de la literatura consagrada garantiza, en principio, la concreción eficaz de esta voluntad "cultural"; 2. Góngora es un poeta barroco, período que coincide con la crisis del imperialismo español y la consecuente crisis financiera y política: época de cuestionamientos al statu quo, como los 60;3. Góngora constituye, en el imaginario, lo opuesto a Garcilaso, el autor "faro" de las poéticas falangistas de la primera posguerra, que cuajaron en grupos y emprendimientos editoriales (revistas) como "Garcilaso" y "Escorial"; 4. Góngora fue, antes de la guerra, reivindicado, también como "faro", por la Generación del 27. Si bien la vanguardia española no fue, en comparación con la francesa, programáticamente política, algunas de sus figuras se pronunciaron ideológicamente, y, por los 60 , cristalizaron, efectivamente, como mitos políticos: Federico García Lorca, el "mártir" desaparecido y muerto, y Rafael Alberti, el "exiliado" eterno; además, algunas zonas de su poesía, como hemos visto, cultivan la tradición "popular".

Segunda pregunta: ¿Por qué estos textos? Respuestas posibles: 1 . porque en ellos Góngora se apoya en las formas de poetizar propias de las poéticas "populares", cuya presencia aquí adquiere aquí función predominante; 2 . porque, consecuentemente, sus "formas" y sus "contenidos" apuntan a ser comprendidos por un público mayoritario, y, dada su virtualidad oral, permiten/exigen su puesta en música. Además, como señala Emilio Orozco (75), Góngora tenía amplios conocimientos musicales, y existe la firme presunción de que estos textos fueron musicalizados por él y recibidos por la corte cantados.

La versión musicalizada de Paco Ibáñez se sostiene, básicamente, en el criterio de abreviación de los textos iniciales, por dos razones fundamentales, que alternan y se complementan: 1. adecuación con la medida standard de la canción en los circuitos de su comercialización (compañías grabadoras, medios); 2. supresión de las zonas "herméticas" en virtud de un receptor no "iniciado". 
ROMANO, M. Un diálogo selecto: Góngora...

Nuestro análisis, ahora, se centrará, prioritariamente, en las variaciones del segundo tipo, que pueden reconstruir la razón de las decisiones del musicalizador.

La primera de las canciones, apoyada en un texto temprano de Góngora, "La más bella niña" (datado por Millé en 1580), es un romancillo-letrilla (romance hexasílabo estribillado) cuya división en seis secuencias clausuradas por estribillo permite pensar en una probable puesta en música contemporánea a su factura verbal. Si bien el molde métrico es de origen popular, Dámaso Alonso señala en él la retórica de contrastes típicamente barroca y rasgos procedentes de la lírica petrarquesca y trovadoresca (1974, v. 2, p. 15). Asimismo, se advierte la preferencia de un discurso conceptista y despojado, en clave sinóptica, que contiene y enmarca el posible desborde sentimental del tópico tradicional: el lamento de la hija ante la madre por la partida del amado a la guerra.

Paco Ibáñez elige del texto la primera, segunda, tercera y quinta estrofas, que reagrupa en el siguiente orden: primera, segunda, quinta y tercera. Deja fuera de su versión la cuarta ("No me pongáis freno...") y la sexta ("Váyanse las noches..."). ¿Razones? La primera es indispensable, argumentalmente, para la comprensión de la anécdota: pone en evidencia el motivo del llanto de la joven. Las otras amplían, ya sea desde el tono elegíaco o sentencioso, este mismo motivo: la segunda y sexta se centran en la experiencia del dolor personal por la pérdida (tono elegíaco), mientras que la tercera y cuarta parten de esa misma experiencia para deslizar aserciones de nivel más general o conclusivo ("pues que no se pueden mejor ocupar"... "harto peor fuera morir o callar").

La redistribución/ selección de Ibáñez apunta a una síntesis del espíritu del texto abarcando estos dos tonos, reorganizándolo con el criterio particular/general. De este modo, las primera (I en TI), funciona, siguiendo al original, como clave argumental; la segunda (II en TI) amplia la historia, ahora en primera persona, en el estricto plano de la subjetividad; la tercera (V en TI) y la cuarta (III en TI) son conclusivas porque, si bien no se desmarcan de la estrategia de la enunciación en primera, apuntan al planteo del tema mediante objetivaciones en tercera persona de esta subjetividad ("¿quién no llorará?", "mis ojos").

Han quedado fuera las estrofas cuarta y sexta del TI probablemente porque: la cuarta tiene "ruidos", trabas fónicas por el uso del castizo de segunda singular "pongáis", "queráis", "queréis", "hagáis", que entorpece el fluir rítmico necesario para la musicalización; la sexta, quizá la más lograda del texto, inexplicablemente fue desechada cuando contiene un ingrediente erótico familiar al programa anticlerical y propicio al "amor libre" del imaginario sesentista, 
tema muy abordado por la canción "de autor" española: "después que en mi lecho/ sobra la mitad".

"Que se nos va la Pascua, mozas" (Millé, 1582), se basa en un romance donde el Góngora burlesco asume festivamente los tópicos tradicionales del "carpe diem" y el "tempus fugit", de los que se ocuparia, junto con su célebre enemigo, Quevedo, en sonetos de tinte "metafísico". En su versión, Ibáñez elimina dos estrofas de las siete que componen el texto. Su selección en esta oportunidad resta dos estrofas de la primera parte introductoria para dejar sólo la primera. El criterio empleado ha sido aquí, claramente, el de facilitación. Las dos estrofas suprimidas dificultan la comprensión frontal del texto en más de un sentido: la segunda ("Vuelan los ligeros años") introduce, como metáfora del tiempo fugaz, la figura de las "harpias" griegas, que robaban los manjares de Fineo; difícilmente un receptor común pueda comprender este guiño, que remite a lecturas pormenorizadas de la enciclopedia clásica; la tercera ("Mirad que cuando pensáis...") ofrece complejidad en su sintaxis y alusiones culturales, por la presencia del hipérbaton en los primeros cuatro versos, y la mención de una expresión lexicalizada en tiempos de Góngora ("por mayores de la marca"), hoy desaparecida. ${ }^{7}$ Por otra parte, lo más rico y atractivo del TI se centra en las estrofas quinta y sexta, que configuran el anecdotario, es decir, la particularización histórica a la vez que paradigmática del tema formulado en la introducción, en los personajes de las "viejas", figuras arquetípicas que recorren la literatura española más demoledora y corrosiva. Dicho anecdotario (estrofas segunda y tercera del TT) permite el ingreso del elemento burlesco, casi esperpéntico, dentro del texto, a partir de recursos que generan el efecto del humor, clave de la intención gongorina, rescatada, para su propio beneficio, por Ibáñez. En este sentido, es notable la fuerza satírica de la comparación de las "mejillas... encogidas y arrugadas" de "una buena vieja" con el "roquete de obispo", o la segunda "vieja" desdentada, cuyo diente acabó, "gag" y metáfora brillantes, "sepultado en unas natas". La conclusión, de tono sentencioso (sexta

7 Dámaso Alonso nos aclara su significado: “«mayor es de la marca» o «de más de la marcas se decía de espadas o de otros objetos que excedían el tamaño que tenían permitido: referido a espadas lo emplea varias veces Cervantes. La expresión se generalizó y pronto pasó a significar "lo que excedía de lo permitido o tolerable» [...] De esta ampliación de significado se vale Góngora para decir que las mozas quedarán perdidas, mayores de la edad propia para el amor". $C f$. ALONSO, p. 22.

8 En esta comparación se desliza una sutil sátira a la jerarquía eclesiástica, por la cual Góngora y su musicalizador se confunden en idéntica sintonía. 
ROMANO, M. Un diálogo selecto: Góngora...

estrofa en TI, cuarta en TT), combina dos imaginarios discursivos, el culto y el popular: en primer lugar, reaparece en el tex to el motivo contrastivo que figura el paso del tiempo por la antítesis "cabello de oro/luciente plata", presente ya en autores del siglo XVI, como Garcilaso, y, a pesar de su procedencia erudita, fácilmente decodificable; en segundo lugar, la "ocasión calva" ("aprovechar el momento"), refrán de indudable raigambre tradicional, al igual que el estribillo que da nombre a la canción.

Dado el criterio de selección adoptado, (que suprime estrofas de tipo sentencioso o filosófico en la Introducción) se desbalancea el tono mixto (serio/ burlesco) del TI en virtud de una reacentuación de su veta cómica, profundamente popular, lo cual genera, por parte del receptor, una adhesión inmediata.

La tercera canción está basada en el texto "Andeme yo caliente..." (Millé, 1581), una letrilla (romance estribillado) de seis estrofas, alusiva a una suerte de hedonismo epicúreo con el que se combinan extrañamente temas surgidos en cl contexto del ascetismo barroco español: indiferencia respecto del poder, la riqueza, el amor. Aquí, nuevamente, el criterio de facilitación es el dominante. El TI, como en el caso anterior, combina alusiones de procedencia popular (la enciclopedia "gastronómica" es, en este sentido, digna de un tratado de las costumbres alimenticias de la época) con cultas: "Filomena" (IV), "Leandro" (V), "Píramo" y "Tisbe" (VI). Ibáñez, no casualmente, excluye las estrofas de mayor complejidad, la quinta y la sexta, que incorpora la figura del amado de Hero, Leandro, y alude al mito de Píramo y Tisbe, poco familiares para el receptor común contemporáneo. La decisión de mantener el nombre de "Filomena" (el ruiseñor, y, translaticiamente, la primavera, en la tradición griega) puede deberse, entre otras razones, a que su decodificación se reduciría aquí a un sustantivo propio de mujer, sin lecturas adicionales, aun cuando, convengamos, no es un nombre de pila común en castellano. Interesa también destacar que Ibáñez mantiene asimismo el estribillo, apoyado en un refrán popular, al que agrega “y rifififí, y rifififá”, de gran efecto fónico-festivo.

La cuarta canción, "Lloraba la niña" (Millé, 1590), es un romancillo en el que se destaca, sobre el molde popular, la apelación a la retórica culta: elipsis ("tantas [lágrimas] como de ellos [de los ojos]"), perífrasis alusivas de carácter mitológico ("el arquero dios"), distorsiones sintácticas ("tantas como de ellos/ un tiempo tiró"), antítesis ("se dejó el silencio/ y llevó la voz"). Sin embargo, la decodificación por parte de un receptor contemporáneo no es dificultosa, entre otras cosas porque los recursos utilizados no abusan de la complejidad distintiva del gongorismo -aquí desplazado por una voluntad "conceptista" de desnudez y concentración semántica. Inclusive, la alusión mitológica a Cupido, "el arquero dios", está, creemos, suficientemente lexicalizada para ser comprendida 
ROMANO, M. Un diálogo selecto: Góngora...

sin mayores obstáculos. Por lo dicho, y dada la brevedad originaria del texto, Ibáñez lo musicaliza en su integridad, incluso transformando en estribillo, junto con el estribillo inicial, parte de la primera secuencia, tal vez el fragmento mejor construido del texto: "Llorando la ausencia/ del galán traidor,/ la halla la luna/ y la deja el sol,/ añadiendo siempre/ pasión a pasión,/memoria a memoria,/dolor a dolor..."

La quinta canción, "Hermana Marica", se basa también en un romancillo de 1580 , de tono autobiográfico, que relata, desde el punto de vista de un niño, los juegos y travesuras infantiles. El Tl es considerablemente extenso (veinte estrofas de cuatro versos), y, curiosamente, Ibáñez suprime poco del original: los dos últimos versos de la estrofa 12; los dos últimos de la 14 y los dos primeros de la 17; en total, una estrofa y media. También curiosa resulta la elección de este texto, que si bien no ofrece dificultades retóricas (la sintaxis, por ejemplo, traduce, en su linealidad -estructuras coordinadas- la ansiedad vital con que la voz relata sus proyectos infantiles), se sostiene en base a un enorme repertorio de alusiones culturales de época (indumentaria, juegos, etc.), cuya comprensión requiere, necesariamente, del auxilio de manuales, diccionarios, etc. ${ }^{9}$ Pese a ello, pervive en la versión la frescura de la descripción infantil, al margen de estos "ruidos" semánticos, $\mathrm{y}$, hacia el final, el relato de las precoces aventuras sexuales, en consonancia con el discurso contestatario y antimoralista de la canción del 60: "porque algunas veces/hacemos yo y ella/ las bellaquerías/ detrás de la puerta". La relación contrastiva entre la visión infantil del mundo (escenificada en el resto del texto) y esta última estrofa, se mantiene también en la versión de Ibáñez, generando un efecto imprevisto que recoloca el poema/la canción en otra serie, de lectura doble o irónica.

Por último, el texto final "Bien puede ser, no puede ser", se basa en un largo poema gongorino de 1581 , que, bajo el molde de la letrilla, pone en evidencia, en clave burlesca, el conflicto barroco apariencia/realidad, tan central, también, en la operación de desmoronamiento que los 60 hacen de la moral burguesa. Dicha letrilla, según consigna en su edición Dámaso, tuvo un éxito y difusión importantes $(1974$, v. 2 , p. 73 ) y resulta probable que algunas de sus partes se mantengan hoy vivas en la tradición folklórica peninsular, por lo que Paco Ibáñez, en este caso, no haría sino dar nombre de autor a unos textos incorporados a la enciclopedia popular. De las veintiún estrofas que conforman

9 Posiblemente, la cubierta de la primera edición de este álbum traería esas referencias, pero no hemos podido verificarlo. 
ROMANO, M. Un diálogo selecto: Góngora...

el TI, la versión final excluye nueve: la quinta, la octava y novena, y la serie comprendida entre la trece y la veintiuna. En esta selección, resulta difícil adivinar las decisiones involucradas, ya que algunas de las elegidas resultan de fácil decodificación y otras no tanto, y ciertas partes excluídas podrían perfectamente haberse integrado a la canción. Lo que sí resulta comprensible es el criterio de haber mantenido las cuatro primeras estrofas en su lugar, lo cual opera como contraseña o guiño de reconocimiento de un texto que, como dijimos, parecería pervivir en el imaginario folklórico contemporáneo.

\section{Algunas reflexiones finales}

Nuestro análisis anterior ha demostrado, al menos sumariamente, algunos desplazamientos entre textos, culturas, imaginarios. Una operatoria de "traducción", en suma, que ha dado cuenta de las travesías que, en más de un sentido, comprometen el diseño de nuestra cultura denominada, polémicamente, "posmoderna": trayectos de voces que relacionan, inesperadamente, cortes cronológicos, poéticas, autores, cuyo vínculo puede resultar, todavía para algunos, impertinente.

De este modo, en esta parte del álbum "Paco Ibáñez", conviven la cultura "pop" y la barroca, el siglo XX y el XVII, el autor popular y el elitista, el afán por la comunicación y el experimentalismo linguísticos, lo popular/culto y lo culto/popular, en una suerte de síntesis que, para ser comprendida, requiere de la crítica una relectura más abierta de la tradición y una comprensión lúcida de los procesos en los que se embarca nuestra cultura contemporánea. En este sentido, es necesario, creemos, atender a los dispositivos de mediación entre campos diversos de la práctica artística e intelectual, más que a la delimitación entre los campos mismos; consecuentemente, resulta imprescindible romper con la mirada jerarquizadora, unitaria e idealista legada por la modernidad para descubrir en las grietas, las zonas grises, los espacios sin nombre claramente atribuible, la riqueza de estas producciones, su importancia como hacer cultural y la condición polémica, desestabilizadora, con que éstas se enfrentan a las teorizaciones hegemónicas.

Para todo ello, la teoría actual en torno a la traducción emerge como el locus especulativo más pertinente para la comprensión de estas prácticas híbridas, polimórficas, "intersemióticas", como la poesía musicalizada. Justamente, porque esta teoría instala su objeto en el lugar que muchas otras dejan vacante: no en los puertos, sino en los tránsitos, en las rutas donde los textos dejaron de ser una cosa para empezar a ser otra, sin serlo todavía (o tal vez nunca) 
ROMANO, M. Un diálogo selecto: Góngora...

plenamente. Es, siempre, en ese sitio sin nombre ( $y$, entonces, con todos los nombres posibles), donde estas textualidades operan, replican, producen, en fin, sus inquietantes mundos de sentido.

\section{RESUMEN}

El presente trabajo tiene como objeto descubrir las claves de una lectura: la que hace Paco Ibáñez de los textos de Luis de Góngora y Argote. Porque es, sin duda, una lectura, esto es, una "versión" particular, en fin, una "traducción", el álbum de Ibáñez editado en 1964, al calor del movimento de la "nueva canción" hispana, que recoge, en su programa formal e ideológico, el primer implso de la poesía "social" consagrada: el retorno a la "inmensa mayoría" de Blas de Otero, la apuesta por el coloquialismo y las hablas populares, el reemplazo del poeta-vidente por el de aquél identificado com el común de los hombres. Por lo mismo, el trabajo apunta a comparar el texto inicial (poema original) com el texto final (canción) com el fin de poner en espejo escrituras, contextos de producción, circulación y consumo, operaciones del imaginario, prácticas estéticas, figuras de autor etc. modernidad.

Palabras-clave: poesía española, canción española, traducción, barroco, pos-

\section{ABSTRACT}

This articles tries to discover a reading's key: the Gongora y Argote texts' read by Paco Ibáñez in a long-play edited on 1964. This record is a particular "versión", actually, a "translation" of the original model, composed by one of the most important singers of tha Spanish "nueva canción" movement. It takes, in its ideological and formal program, the "social" poetry's first impulse: the return to the "inmensa mayoria" wished by Blas de Otero, the uses of coloquialism and popular codes, the replacement of the propher poet by the poet who wants to seem as the common man. In this way, our article wants to compare the original text (poem) with the final text (song), trying to put in relation writings, contexts of production, circulation and reception, ways of thinking and seeing, aestetics praxis, images of authors etc.

Key-words: Spanish poetry, Spanish song, translation, Baroque, post-modernity. 
ROMANO, M. Un diálogo selecto: Góngora...

\section{BIBLIOGRAFÍA CONSULTADA}

ALONSO, Dámaso. Góngora y el Polifemo. v. 2. Madrid: Gredos, 1967.

GÓNGORA, Luis de. Soledades. Edición, introducción y notas de Dámaso Alonso. Madrid: Alianza, 1980.

. Soledades. Edición, introducción y notas de John Berverly. Madrid: Cátedra, 1985.

GARCÍA BERRÍO, A. Las letrillas de Góngora (Estructura pragmática y liricidad del género. In: Edad de Oro, v. 2, p. 89-97, 1983.

GARCÍA LORCA, Federico. La imagem poética en Don Luis de Góngora. In: Obras completas. v. 7. Bs. As.: Losada, 1953. p. 85-116.

JAMMES, Robert. Elementos burlescos en las Soledades de Góngora. In: Edade de Oro, v. 2, p. $99-117,1983$.

OROZCO DÍAZ, Emilio. Introducción a Góngora. Barcelona: Crítica, 1984.

ROMANO, Marcela. Escribir, decir, cantar: una utopía empecinada. Charlando com José Agustín Goytisolo y Paco lbáñez. Revista del CELEHIS, año 4, v. 4/5, p. 323-331, 1995. 